Ya. Garashchenko, N. Zubkova, Kharkiv, Ukraine

\title{
EVALUATION OF THE FORECASTED EFFICIENCY OF PERFORMANCE OF RATIONAL ORIENTATION OF THE PRODUCT IN THE WORKSPACE OF ADDITIVE INSTALLATIONS
}

\begin{abstract}
Preliminary evaluation of the predicted efficiency of the optimization problem of the rational orientation of the product in the working space of layered construction of additive units is proposed to perform based on the analysis of the original triangulation 3D-model of a complex product by its spherical mapping. The condition of reflection on the sphere is that the values of angles in the spherical coordinate system for the faces normal of the triangulated model of product fall into the range of values of a certain triangular face of the sphere model. Examples of evaluation based on the analysis of spherical mapping of the original 3D model of products are considered. Industrial products with different surface complexity were selected as test $3 D$ models. This approach allowed to perform a comparative analysis of the results depending on the design features of the products. The practical implementation was performed in the subsystem of visual assessment of geometric characteristics of triangulated $3 D$-models, which is part of the technological preparation system for the complex product manufacture by additive methods. This system was developed in NTU "KhPI" Department of Integrated Technologies of Mechanical Engineering named after M.F. Semko.
\end{abstract}

Keywords: technology planning; additive manufacturing; triangulated model; assessment of manufacturability, product orientation in the workspace.

Introduction. The current direction of research aimed at improving the efficiency of the assessment of manufacturability, design improvement and reasonable choice of manufacturing strategy by additive technologies is the development of DfAM (Design for Additive Manufacturing) approaches [1].

When it comes to additive technologies, the source geometric information for manufacturing is a triangulated 3D-model of an industrial product, usually in STL format [2]. The triangulated model unifies the representation of the product surface, which creates the preconditions for the analysis of the system of triangular faces without restrictions concerning the structural complexity.

One of the main optimization problems of the technological preparation of additive processes is to determine the rational orientation of the product in the workspace of the layered build of the installation [3,4]. The possibility of solving this optimization problem significantly depends on the geometric complexity of the product surfaces. Preliminary assessment of the design (component surfaces) of the product in the technological preparation for adaptation to the definition of rational orientation is of interest to ensure the required level of efficiency of the processes of the layered build.

Literature analysis. As a rule, the choice of the rational orientation of the product is performed by solving the optimization problem using a set of criteria 
$[3,5]$. The orientation option is chosen to take into account the most important factors. Since the orientation affects many factors, its choice during construction is based on the following:

- surface quality characteristics, building time, complexity, and volume of auxiliary support structures [6];

- the number of construction layers [7];

- the height of the product on the coordinate axis $Z[8,9]$;

- the area of the surfaces in contact with support structures (the area of the faces of the triangulated model with the coefficient of the normal on $Z$-axis in a given range of values) [8];

- surface error (the area of the faces with normal that are not perpendicular or parallel to the $Z$-axis, ie $\left|N_{Z}\right| \neq 1$ and $N_{Z} \neq 0$ [7], the area of the faces with normal $\left|N_{Z}\right|=1$ and $N_{Z}=0$ [10], the difference between the volumes of the original 3Dmodel and the ready-made product [8]);

- physical and mechanical properties of the product [8].

Despite a large number of works [3-13] to solve this problem, there is still no scientifically based quantitative assessment of the manufacturability of the product to the definition of rational orientation. Therefore, to test the design for adaptability to determine the rational orientation of the product in the working space, it is necessary to develop a special assessment that takes into account the features of layered manufacturing.

Taking into account the works $[6,14]$, to determine the rational orientation the angle between the normal of the triangular faces and the vector of the build direction ( $Z$ coordinate axis) is chosen as the studied feature of the triangulated 3Dmodel of the product. This investigated feature is the most significant of the geometric properties of the triangulated 3D-model, because it determines the roughness and errors in shaping the surfaces of the product, and therefore, the building step. Surfaces with a negative angle of inclination of the normal towards the $Z$-axis determine the design of support structures and, therefore, the complexity of post-processing processes for their removal.

The purpose of the article is to substantiate the possibility of a quantitative assessment of the manufacturability of the structure as for the task of determining the rational orientation of the product in the working area of layered building based on the analysis of the spherical reflection of the triangulated 3D-model.

Research methodology. The research was performed using the subsystem of visual analysis of the triangulation 3D-model of the product (screen form is presented in Fig. 1), designed to test its design in solving problems of technological preparation. The subsystem is a part of the system of technological preparation for the materialization of complex products by additive technologies, developed at the Department of Integrated Technologies of Mechanical Engineering named after M.F. Semko in NTU "KhPI". This system allows to 
assess the manufacturability of the product design and analyze the effectiveness of additive technologies in its manufacture.

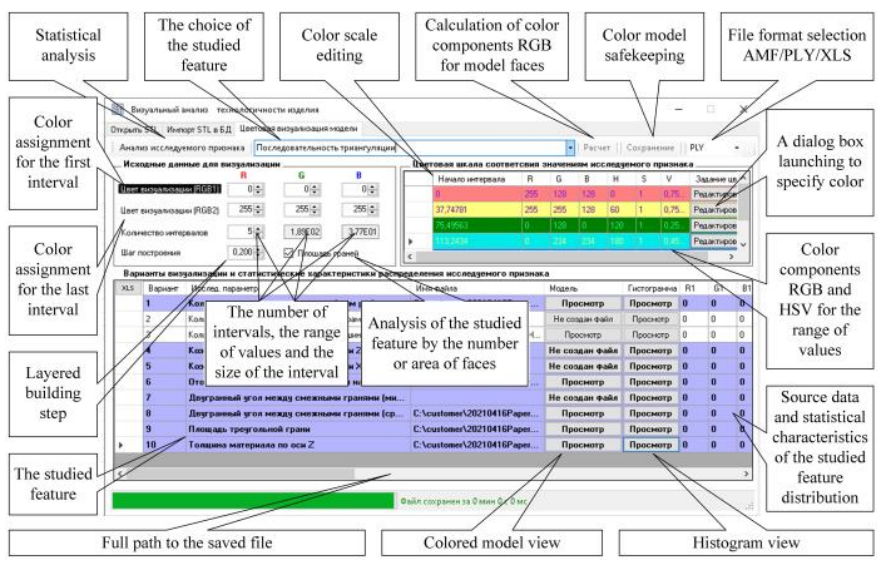

Figure 1 - Screen form of the subsystem of visual analysis of the product 3D-model

When developing the subsystem of visual analysis (color visualization) of the triangulated product model, the following main tasks were solved:

- assessment of correctness and rationality of triangulation of CAD-model;

- testing the subsystem manufacturability;

- visual assessment of the possibility of determining the rational orientation of the product in the working area of construction (examples are presented in Fig. 2).

The subsystem allows to perform color visualization on the surface of the model and statistical analysis of the distribution of values according to the selected feature of the 14 proposed characteristics $[15,16]$;

For additive technologies with layered building, the greatest roughness and deviations from the correct shape of surfaces are observed for faces that have an angle between their normal and the vector of the building direction (coordinate axis Z) $\alpha_{N Z}$ in a certain range of values. The following intervals of values are conditionally distinguished: $\alpha_{N Z}\left(0^{\circ}, \alpha_{N Z l i m i t}\right)$ and $\alpha_{N Z}\left(180-\alpha_{N Z}\right.$ limit, $\left.180^{\circ}\right)$ [17]. The threshold value of the angle $\alpha_{N Z}$ limit $\left(30^{\circ}, 50^{\circ}\right)$ depends on the chosen AMmethod, technological characteristics of the equipment, source material and for some AM-methods (SLA, SLM, FDM, etc.) on the requirements of support structures [18]. Surfaces with the smallest deviations of the form have an angle $\alpha_{N Z}$ $\left(\alpha_{N Z_{-} \text {limit }}, 180-\alpha_{\text {NZ_limit }}\right)$. The minimum value of deviations is a characteristic for surfaces with angles $\alpha_{N Z}=\left\{0^{\circ} ; 90^{\circ}\right\}$, i.e., for horizontal (directly formed without contact with the support structure or with the medium from the source material) 
and vertical surfaces. For horizontal hanging surfaces, i.e., those which are with an angle $\alpha_{N Z}=180$, for example, for FDM such surfaces are ideal only if they are adjacent to the table.

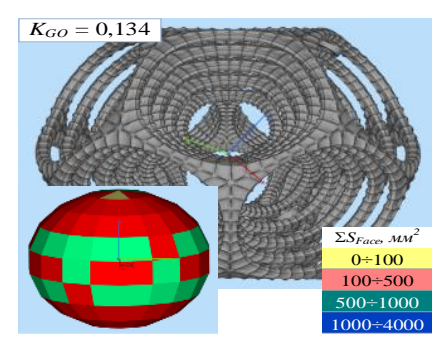

a)

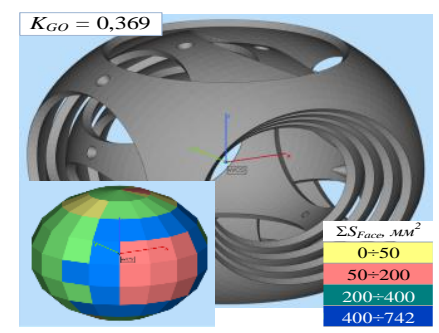

c)

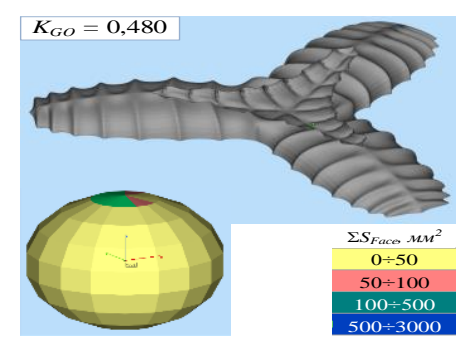

b)

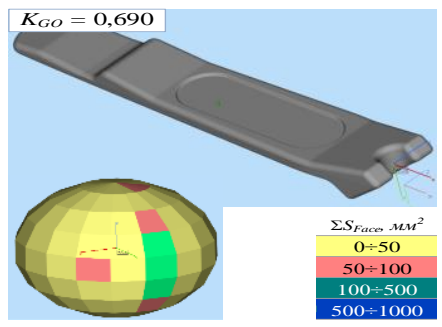

d)

Figure 2 - Examples of color visualization by mapping to a triangulated sphere the total area of the faces of triangulated models of products at intervals of angles $\theta$ and $\varphi$ for vectors of normal faces in a spherical coordinate system (the obtained calculation data and their statistical analysis for the presented test 3D-models $a$ - $d$ are shown in Fig. 3 and in Table 1)

In technological preparation, the visualization of a product 3D-model by adding color to the surface areas depending on the value of the coefficient $N_{Z}$, offers information for decision-making on creating support structures and subsequent processing. But such visualization has obvious limitations for products that have internal surfaces (cavities) and a large number of complex-shaped surfaces. Therefore, to remove the restrictions imposed by the features of the studied design, it is proposed to perform the mapping of the product model to the sphere (color scale of the studied feature - the total area of the faces). The condition for mapping to the sphere is that the angles in the spherical coordinate system for the normal faces of the 3D-model of the product fall into the range of 
values of a certain face of the triangulation sphere model $[19,20]$. The angles in the spherical coordinate system for the normal faces of the 3D-model are calculated using the coefficients of the unit vector of the normal $N_{X}, N_{Y}, N_{Z}$ [20].

The examples of spherical display of test 3D-models of products, presented in Fig. 2, show a high enough level of informativeness to determine the rational orientation. The problem of determining the rational orientation of the product in the workspace using a spherical map is to orient the surface with a larger area so that the normals of their faces are in a given range of values of their angles in the spherical coordinate system. In this case, the minimum error of layered shaping of the product surfaces is provided [3-13].

The proposed approach (visualization) also demonstrates the possibility of working out the design (assessment of the suitability of the 3D-model) for the rational orientation of the product in the working area of construction [19]. This creates the conditions for quantitative assessment of the manufacturability of the product based on the data of the distribution of the area of the 3D-model faces taking into account the intervals of reflection on the sphere.

It seems most appropriate to assess the suitability of the structure to the orientation by determining the deviations from the uniform distribution of the areas of the faces reflected on the sphere. The sphere model, as a product, is the least suitable for solving this problem. Therefore, the hypothesis is proposed that the efficiency of the rational product orientation can be a coefficient of concentration of the density of the surface area distribution along the triangular faces of the sphere reflection (by the angles of inclination of the normals of the triangular faces of the 3D-model $\theta$ and $\varphi$ in the spherical coordinate system) [21]:

$$
K_{G O}=\frac{1}{2} \sum_{i, j}^{n, m}\left|D_{i j}-d_{i j}\right|,
$$

where $n, m$ is the number of intervals for angles $\theta \in[0,180)$ i $\varphi \in[0,360)$ in the spherical coordinate system for the normals of the triangular faces of the $3 \mathrm{D}$ model, respectively (recommended value $n=4 \div 6, m=2 n ; D_{i j}$, $d_{i j}$ - the relative area of the faces of 3D-models of the product and the sphere, respectively, that fall into the $i j$-th region of the values of angles $\theta$ and $\varphi$ for the normals, $d_{i j}=1 / \mathrm{nm}$;

In case of uniform distribution of the investigated feature (product surface area) when mapping to the sphere $d_{i j}=1 / n_{t r_{-} \text {sphere }}$, where $n_{t r_{-} \text {sphere }}$ is the number of triangular polygons of the sphere.

Spherical display of the sphere 3D-model as a function (1) will have a coefficient $K_{G O}=0$. Such value of the coefficient demonstrates the lack of a rational solution for the orientation of the sphere. Obtaining a larger coefficient of $K_{G O}$ will indicate the possibility of determining the smaller area of values of the product rotation angles for its rational orientation. That is, a smaller relative 
number of variants of the rational orientation of the product model, and accordingly a simpler solution of the optimization problem.

Results of the research. The hypothesis was tested by calculating $K_{G O}$ coefficient using dependence (1) for test 3D-models of complex products mapped to the triangulation model of the sphere $(n=6, m=12$, respectively $\Delta \theta=\Delta \varphi=20^{\circ}$ ). The chart of the distribution density of the number of 3D-models by $K_{G O}$ coefficient is presented in Fig. 3.

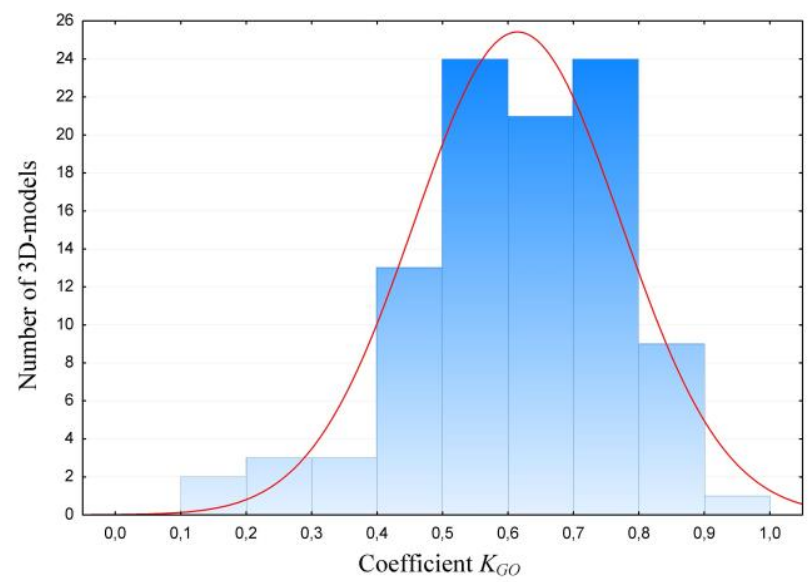

Figure 3 - Chart of the distribution density of the number of 3D-models by the value of coefficient $K_{G O}$

The set of test 3D-models is a sample of a sufficiently large group of products that were manufactured on SLA (laser stereolithography), SLS (selective laser sintering), and FDM (fused deposition modeling). The sample size was 100 products.

Statistical analysis of $K_{G O}$ coefficients allowed to determine the following characteristics:

- minimum, maximum and arithmetic mean $\left\{K_{G O}\right\}_{\min }=0.107$, $\left\{K_{G O}\right\}_{\max }=0.909, \overline{K_{G O}}=0.611$, respectively;

- lower and upper quartiles $Q_{1}\left\{K_{G O}\right\}=0.519$ and $Q_{3}\left\{K_{G O}\right\}=0.733$, respectively;

- standard deviations $\left\{K_{G O}\right\}=0.016$.

Comparative analysis of $K_{G O}$ coefficients (Fig. 2,3) on the example of a sample of 3D-models of products also confirmed the hypothesis. As the value of $K_{G O}$ coefficient decreases, the predicted efficiency of the problem of determining 
the rational orientation of the product in the construction workspace reduces. The evaluation of the product design by $K_{G O}$ coefficient is justified for the cases of solving this optimization problem according to the criteria that depend on the location of the surfaces, i.e. the area of the 3D-model faces and their orientation. Such optimization criteria include statistical characteristics of surface roughness and deviation from the correct shape of surfaces.

Based on the analysis of the results of calculations and manufacturing practices of the considered products for models with coefficient $K_{G O}<0.4 \div 0.5$ (for $15 \div 25 \%$ $3 \mathrm{D}$-models of products) the surface quality and accuracy of shaping should be neglected and the following optimization criteria should be chosen for rational orientation of the product: the height of the product gravity center, construction height, number of layers or construction time. For $K_{G O}>0.5 \div 0.6$ (for most product 3D-models), multicriteria optimization should be considered.

It is important to determine the rational degree of detail (the number of intervals of values of the angles of inclination of the normals) reflection on the sphere. Therefore, $K_{G O}$ coefficients were additionally determined for a small group of 3D-models of products (Fig. 2) for several intervals of values of angles $\theta, \varphi=\left\{5^{\circ} ; 10^{\circ} ; 20^{\circ} ; 30^{\circ}\right\}$. The values of $K_{G O}$ coefficients are given in table 1.

Analysis of the values of $K_{G O}$ coefficient presented in table 2 shows their growth as the sphere detail increases, and therefore, the number of intervals of values of angles $\theta, \varphi$ rises. This increase in $K_{G O}$ demonstrates the increase in the manufacturability of the structure as the accuracy of determining the rational orientation of the product in the construction working space rises. To ensure a comparative assessment of manufacturability of products, it is proposed to use a sphere to display 3D-models with the interval of values of angles $\theta, \varphi=\left\{20^{\circ} ; 30^{\circ}\right\}$.

In the case of mass customized additive production to ensure automated technological preparation, it is of interest to group products according to $K_{G O}$ coefficient. This approach will allow using uniform technological techniques for a group of products with similar $K_{G O}$ s to solve the problems of orientation and their placement in the working space of layered construction. This approach creates opportunities to minimize the cost of technological preparation and increase the efficiency of the subsequent problem of forming a set of layers according to the adaptive strategy with a variable construction step.

Table 1 - Coefficients of the suitability of test 3D-models of industrial products to determine the rational orientation of $K_{G O}$

\begin{tabular}{|l|c|c|c|c|}
\hline \multirow{2}{*}{ Test model } & \multicolumn{4}{|c|}{ The intervals of values of angles $\theta, \varphi$ in the spherical coordinate system } \\
\cline { 2 - 5 } & $30^{\circ}$ & $20^{\circ}$ & $10^{\circ}$ & $5^{\circ}$ \\
\hline 1 (Fig. 2a) & 0.109 & 0.134 & 0.173 & 0.202 \\
\hline 2 (Fig. 2b) & 0.429 & 0.480 & 0.500 & 0.572 \\
\hline
\end{tabular}


$\underline{\text { ISSN 2078-7405 Cutting \& Tools in Technological System, 2021, Edition } 94}$

\begin{tabular}{|l|l|l|l|l|}
\hline 3 (Fig. 2c) & 0.323 & 0.369 & 0.437 & 0.496 \\
\hline 4 (Fig. $2 d$ ) & 0.581 & 0.690 & 0.778 & 0.802 \\
\hline
\end{tabular}

Conclusions. The proposed relative indicator $K_{G O}$ to assess the effectiveness of determining the rational orientation of the product according to the quality criteria of the obtained surfaces allows with high informativeness to assess manufacturability (design suitability) for its manufacture by additive technologies. $K_{G O}$ coefficient determines the relative number of rational options from the set regarding the orientation of the product in the workspace of the layered building.

Manufacturability assessment to determine the rational orientation in the workspace allows to group products with similar indicators. This approach will allow ensuring the greatest efficiency of manufacturing technology in terms of roughness and accuracy of the resulting surfaces by defining a unified manufacturing strategy for a group of products with similar design features.

References: 1. Diegel O., Nordin A., Motte D. A Practical Guide to Design for Additive Manufacturing. Springer Series in Advanced Manufacturing, 2019, doi: 10.1007/978-981-13-8281-9. 2. Gibson I., Rosen D., Stucker B., Khorasani M. Additive manufacturing technologies. 3rd Edition. Cham (Switzerland): Springer Nature Switzerland AG, 2021, 675 pp., doi: 10.1007/978-3-030-56127-7. 3. Eranpurwala A., Ghiasian S.E., Lewis K. Predicting Build Orientation of Additively Manufactured Parts With Mechanical Machining Features Using Deep Learning. Proceedings of the ASME 2020 International Design Engineering Technical Conferences and Computers and Information in Engineering Conference. Volume 11A: 46th Design Automation Conference (DAC). Virtual, Online. August 17-19, 2020, V11AT11A023. ASME., doi: 10.1115/DETC2020-22043. 4. Hong S., Byun K., Lee $H$. Determination of optimal build direction in rapid prototyping with variable slicing. Int. J. Adv. Manuf. Technol. 2006, No. 28. P. 307-313, doi: 10.1007/s00170-004-2355-5. 5. Canellidis V., Giannatsis J., Dedoussis V. Genetic-algorithm-based multi-objective optimization of the build orientation in stereolithography. Int J Adv Manuf Technol, 2009, 45: 714-730. doi: 10.1007/s00170009-2006-y. 6. Singhal S.K., Pandey A.P., Pandey P.M., Nagpal A.K. Optimum part deposition orientation in stereolithography. Computer-Aided Design \& Applications. 2005, Vol. 2, Nos. 1-4, pp. 319-328. 7. Bablani M., Bagchi A. Quantification of errors in rapid prototyping processes, and determination of preferred orientation of parts, Transactions of the North American Manufacturing Research Institution of the SME, Vol. XXIII, SME, Houghton, Ml, May 1995, pp. 319-324. 8. Thompson D.C., Crawford R.H. Optimizing part quality with orientation, in Marcus, H.L. et al. (Eds), Solid Freeform Fabrication Symposium 1995, University of Texas, Austin, August 1995. 9. Vitjazev Ju.B. Rasshirenie tehnologicheskih vozmozhnostej uskorennogo formoobrazovanija sposobom stereolitografii: Dis... kand. tehn. nauk: 05.02.08, Kharkiv, 2004, 228 p. 10. Pat. 54398U UKRAYINA, MPK B29C 35/08, B29C 41/02, G06F 17/50, G06F 19/00. Sposib posharovoyi pobudovy vyrobiv na bazi vykhidnoyi trianhulyatsiynoyi 3D modeli / Abdurayimov L.N., Chernyshov S.I., Dobroskok V.L., Vityazyev Yu.B.; zayavnyk i patentovlasnyk Nats. tekhn. un-t "Kharkivs'kyy politekhn. in-t". - № u201004548; Zayavl. 19.04.2010; Opubl. 10.11.2010, Byul. № 21. 11. Moroni G., Syam W. $P$., Petrò S., Functionality-based Part Orientation for Additive Manufacturing, Procedia CIRP, 2015, 36, pp. 217-222. 12. Zhang Y., Bernard A., Gupta R. K., Harik R. Feature Based Building Orientation Optimization for Additive Manufacturing, Rapid Prototyping Journal, 2016, 22(2), pp. 358-376. 13. Rocha A. M. A., Pereira A. I., Vaz, A. I. F. Build Orientation Optimization Problem in Additive Manufacturing, Proc. International Conference on Computational Science and Its Applications, Springer, 2018, pp.669-682. 14. Abdurajimov L.N. Povyshenie jeffektivnosti integrirovannyh tehnologij poslojnogo vyrashhivanija izdelij putem morfologicheskogo analiza ih $3 \mathrm{D}$ obraza na jetape podgotovki 
k materializacii: Dis. kand... tehn. nauk: 05.02.08. Kharkiv: NTU "Khark. pol. in-t.", 2012, 264 p. 15. Ranjan Rajit, Samant Rutuja, Anand Sam. Design for manufacturability in additive manufacturing using a graph based approach. In: ASME 2015 International Manufacturing Science and Engineering Conference. American Society of Mech. Engineers, 2015, pp. 1-10. doi: 10.1115/MSEC2015-9448. 16. Shwe P. Soe. Quantitative analysis on SLS part curling using EOS P700 machine, Journal of Materials Processing Technology, 212 (2012), pp. 2433-2442. doi: 10.1016/j.jmatprotec.2012.06.012. 17. Daekeon A., Hochan K., Seokhee L. Fabrication direction optimization to minimize post-machining in layered manufacturing, International Journal of Machine Tools and Manufacture, Volume 47, Issues 3-4, March 2007, pp. 593-606. doi: 10.1016/j.ijmachtools.2006.05.004. 18. Kumke M., Watschke H., Vietor T. A new methodological framework for design for additive manufacturing. Virtual And Physical Prototyping Vol. 11, Iss. 1, 2016, pp. 3-19. doi: 10.1080/ 17452759.2016.1139377. 19. Garashchenko Ya. Vizualna otsinka mozhlyvosti ratsionalnoi oriientatsii vyrobu pry posharovii pobudovi na ustanovkakh adytyvnykh tekhnolohii. Visnyk ZhDTU. Seriia: Tekhnichni nauky. Zhytomyr: ZhDTU, T. 1, № 2(80), 2017, pp. 3-10. doi: 10.26642/tn-2017-2(80)-3-10. 20. Garashchenko Ya. Otsenka yskhodnoi 3D-modely na prysposoblennost k opredelenyiu ratsyonalnoi oryentatsyy yzdelyia pry posloinom postroenyy. Rezanye y ynstrument v tekhnolohycheskykh systemakh, 2017, Vip. 87, pp. 28-40. 21. Podgornyj A.Z., Mylashko O.G., Kirsho S.M., SHilofost N.M. Statistika: Uchebnoe posobie dlya inostrannykh studentov, Odessa: Atlant, 2012, 195 p.

\title{
Ярослав Гаращенко, Ніна Зубкова, Харків, Україна \\ ОЦІНКА ПРОГНОЗОВАНОЇ ЕФЕКТИВНОСТІ ВИКОНАННЯ ЗАДАЧІ РАЦІОНАЛЬНОЇ ОРІЕНТАЦІЇ ВИРОБУ У РОБОЧОМУ ПРОСТОРІ АДИТИВНИХ УСТАНОВОК
}

\begin{abstract}
Анотація. Запропоновано виконувати попередню оцінку прогнозованої ефективності оптимізаційної задачі рачіональної орієнтації виробу у робочому просторі пошарової побудови адитивних установок на основі аналізу вихідної тріангуляційної 3D-моделі складного виробу шляхом ї̈ сферичного відображення. Умовою відображення на сферу є потрапляння значень кутів в сферичній системі координат для нормалей граней тріангуляційної моделі виробу в область значень певної трикутної грані моделі сфери. Розглянуто приклади оцінки на основі аналізу сферичного відображення вихідної 3D-моделі виробу. В якості тестових $3 D$-моделей обрані промислові вироби з різною складністю поверхонь. Такий підхід дозволив виконати порівняльний аналіз результатів в залежності від конструктивних особливостей виробів. Найбільш дочільним видається оцінка пристосованості конструкиіі виробу до виконання оптимізаційної задачі раціональної орієнтації иляхом визначення відхилень від рівномірного розподілу площ граней відображених на сферу. Запропонований відносний показник для оцінки ефективності визначення раціональної орієнтації виробу за критеріями якості отриманих поверхонь дозволяе з досить високою інформативністю оцінювати технологічність (пристосованість конструкиії) для його виготовлення адитивними технологіями. Такий показник визначає відносну кількість рачіональних варіантів з множини можливих щодо орієнтації виробу у робочому просторі адитивної установки. Практична реалізація виконувалась у підсистемі візуальної оцінки геометричних характеристик тріангуляційних $3 D$ моделей, щчо входить до системи технологічної підготовки виготовлення складних виробів адитивними методами. Дану систему розроблено на кафедрі «Інтегровані технологіі машинобудування» НТУ «ХПI».
\end{abstract}

Ключові слова: технологічна підготовка; адитивні технологї; тріангуляційна модель; оцінка технологічності, орієнтація виробу у робочому просторі. 